\title{
Hubungan Perhatian Orang Tua Terhadap Hasil Belajar Kognitif Siswa
}

\author{
Arifudin Mahmudi ${ }^{1}$, Joko Sulianto ${ }^{2}$, Ikha Listyarini ${ }^{3}$ \\ Jurusan Pendidikan Guru Sekolah Dasar, Fakultas IImu Pendidikan \\ Universitas PGRI Semarang \\ e-mail: mahmudi.arif25@gmail'com ${ }^{1}$, Sulianto.jo@gmail.com² Ikhalistyarini@upgris.ac.id ${ }^{3}$
}

\begin{abstract}
Abstrak
Perbedaan pemberian perhatian orangtua terhadap siswa di SDN Banjarsari Kecamatan Ngadirejo Kabupaten Temanggung diduga memiliki hubungan terhadap hasil belajar kognitif yang diperoleh siswa. Permasalahan dalam penelitian ini adalah bagaimanakah hubungan perhatian orangtua terhadap hasil belajar kognitif siswa kelas IV. Jenis penelitian kualitatif dengan pendekatan deskriptif. Sumber data penelitian yaitu siswa kelas IV dan orangtua siswa kelas IV. Prosedur pengumpulan data yang digunakan adalah observasi, angket, wawancara dan dokumentasi. Hasil penelitian menunjukan data perhatian orangtua dengan kategori sangat cukup diperoleh 9 siswa dengan presentase 24,3\%, perhatian orangtua dengan kategori cukup diperoleh 12 siswa dengan presentase $32,4 \%$, perhatian orangtua dengan kategori kurang diperoleh 11 siswa dengan presentase 29,7\%, perhatian orangtua dengan kategori sangat kurang diperoleh 5 siswa dengan presentase 13,6\%. Rata rata hasil belajar kognitif siswa dengan kategori sangat baik diperoleh 20 siswa dengan presentase $54,1 \%$, rata rata hasil belajar kognitif siswa dengan kategori baik diperoleh 11 siswa dengan presentase 29,7\%, rata rata hasil belajar kognitif siswa dengan kategori cukup diperoleh 6 siswa dengan presentase $16,2 \%$. Jadi,perhatian orangtua memiliki korelasi dengan hasil belajar kognitif siswa.
\end{abstract}

Kata-kata kunci: perhatian orangtua, hasil belajar kognitif

\begin{abstract}
The differences in giving parents' attention to students at SDN Banjarsari, Ngadirejo Sub district, Temanggung Regency, are thought to have a relationship to cognitive learning outcomes obtained by students. The problem in this research is how parents' attention to the cognitive learning outcomes of fourth grade students. Type of qualitative research with a descriptive eapproach. Sources of research data are fourth grade students and fourth grade parents. Data collection rules used are observation, questionnaire, interview and documentation. The results showed that parental attention data with a very enough class were obtained 9 students with a percentage of $24,3 \%$, parental attention with a sufficient class were obtained 12 students with a percentage of $32,4 \%$, parental attention in the less class obtained by 11 students with a percentage of $29,7 \%$, parents' attention in the class of very little wa obtained by 5 students with a percentage of 13,6\%. The average cognitive learning outcomes of students with excellent categories were obtained by 20 students with a percentage of $54,1 \%$, the average cognitive learning outcomes of students with good categories were obtained by 11 students with a percentage of $29,7 \%$, the average cognitive learning outcomes of students with sufficient categories were obtained 6 students with a percentage of $16,2 \%$, it was concluded that parental attention has a correlation with student cognitive learning outcomes.
\end{abstract}

Keywords: parental attention, cognitive learning outcomes

\section{Pendahuluan}

Pendidikan adalah kebutuhan yang penting bagi kehidupan manusia, pendidikan dapat mengatur dan menata kehidupan manusia agar menjadi lebih baik. Education takes an important place in developing human intellectuality that are able to: 1) do technological literacy, 2) make an effective communication, 3) think critically, 4) solve the problems, and 5) collaborate with other. Sulianto, Sunardi, Anitah, Gunahardi dalam (Universal Journal of Educational Research 8(3D): 60-66, 2020). 
Pendidikan tidak hanya guru yang berperan penting untuk mendidik anak, tetapi juga orang tua. Hal ini sesuai dengan Undang undang Republik Indonesia No. 20 Tahun 2003 bab IV pasal 7 tentang hak dan kewajiban orang tua yang berbunyi. Butir 1 yaitu orang tua berhak berperan serta dalam memilih satuan pendidikan dan memperoleh informasi tentang perkembangan anaknya, dan butir ke 2 yang berbunyi orang tua dari anak usia wajib belajar, berkewajiban memberikan pendidikan dasar kepada anaknya.

Hak dan kewajiban orang tua terhadap anak yaitu dengan memberikan bimbingan dan pendidikan yang baik bagi anak. Seorang anak mendapatkan pendidikan pertama kali dari orang tua dan keluarga. Pendidikan tersebut sebagai modal dasar anak masuk SD inilah anak mulai menerima perkembangan perkembangan yang membantu dirinya dalam menerima pelajaran yang diberikan oleh gurunya. Selain itu pada masa SD ini pula anak mulai siap menjelajahi dan mempelajari lingkungannya. Karena pada masa ini anak tidaklah puas hanya sebagai penonton saja melainkan anak ingin mengetahui lingkungannya, bagaimana perasaan perasaan serta bagaimana anak dapat menjadi bagian dari lingkungannya. Apalagi pada masa masa anak usia kelas tinggi, yang mana pada masa ini anak mulai melakukan hal yang sesuai dengan apa yang anak fikirkan tanpa memperdulikan otoritas atau nasihat serta bimbingan orang tua dan gurunya. Pada masa ini orang tua dan guru harus saling bekerja sama dalam upaya membangkitkan semangat siswa dalam belajar dan membimbing siswa agar lebih baik.

Orang tua dan guru bertugas penting dalam membangkitkan semangat siswa dalam belajar untuk mencapai masa depan siswa. Orang tua merupakan salah satu factor penentu keberhasilan anak dalam belajar. Perhatian orangtua atau keluarga dalam mendidiki dan memberikan motivasi belajar, memiliki peranan aktif yang dapat menjadi sumber semangat baru untuk anak, sehingga anak lebih termotivasi dalam belajar.

Perhatian menurut Slameto (2010: 105) adalah kegiatan yang dilakukan seseorang dalam hubungannya dengan pemilihan rangsangan yang datang dari lingkungannya. Dari pengertian tersebut dapat diketahui bahwa perhatian merupakan kegiatan yang dilakukan dengan memusatkan kosentrasi terhadap suatu objek. Perhatian dilakukan berdasarkan rangsangan yang diterima dari apa yang individu dapat dari lingkungannya.

Perhatian merupakan pemusatan atau kosentrasi yang menyebabkan bertambahnya aktivitas individu terhadap suatu objek. Dengan kata lain, perhatian orang tua merupakan pemusatan atau kosentrasi orang tua terhadap anaknya yang menyebabkan bertambahnya aktivitas seorang anak, terutama dalam pemenuhan kebutuhan baik secara fisik maupun non fisik. Akan tetapi dalam memberikan perhatian, orang tua tidak boleh berlebihan ataupun kekurangan, tetapi harus sesuai dengan kebutuhan atau ideal. Perhatian orang tua yang berlebihan akan mengakibatkan anak stress dan tertekan dan sebaliknya apabila perhatian orang tua yang kurang maka akan mengakibatkan anak dalam memenudi kebutuhannya tidak sesuai dengan harapan. Yang dimaksud dengan perhatian sesuai kebutuhan atau ideal adalah perhatian yang berhubungan dengan bagaimana cara orang tua mendidik anaknya sesuai kadarnya.

Prestasi belajar sangat berkaitan dengan perhatian orang tua. Dapat diketahui pendidikan pertama seorang anak adalah dari komponen keluarganya yaitu orang tua. Sekolah hanya menjadi pendidikan pengembang. Anak akan tumbuh cerdas jika orang tuanya selalu memperhatikan dan selalu member dorongan berupa semangat kepada anaknya. Tidak hanya memberi materi finansial saja.

Motivasi belajar dari orang tua merupakan suatu dorongan atau penggerak bagi seorang siswa untuk berprestasi dalam belajar dengan melakukan suatu tindakan untuk mencapai tujuan pembelajaran yang telah ditentukan. Dengan adanya penjelasan mengenai perhatian orang tua dan prestasi belajar tersebut, dapat diketahui bahwa orang tua berada dalam garis depan pendidikan yang berhadapan secara langsung dengan anak, melalui proses internalisasi sikap dan perilaku belajar. Dalam hal ini, anak sebagai wahana pemberian perhatian dan motivasi sebagai tolak ukur prestasi belajar seorang anak tersebut. Perhatian orang tua diberikan oleh orang tua terhadap anak dapat memotivasi siswa dalam melakukan kegiatanya, termasuk memotivasi anak untuk belajar (Journal Student UNY : 975).

Berdasarkan observasi di SD Negeri Banjarsari, peneliti mendapat informasi mengenai latar belakang pekerjaan orang tua siswa, khususnya siswa kelas 4 SD Negeri Banjarsari Kecamatan Ngadirejo Kabupaten Temanggung. Yang sebagian besar pekerjaan orang tua siswa adalah petani dan buruh. Kemudian sisanya berkerja sebagai pegawai.

Berdasarkan hasil pengamatan peneliti, Orang tua siswa yang bekerja sebagai petani dan buruh adalah lulusan sekolah dasar, sehingga orang tua siswa kurang memahami pendidikan anaknya. Orang tua lebih disibukan dengan pekerjaan untuk mencukupi keluarga, 
bahkan sebagian orang tua siswa ada yang berkerja menjadi buruh pabrik dan kuli bangunan di luar daerah dalam waktu lama, sehingga waktu untuk berada di lingkungan keluarga sangat terbatas dan mengakibatkan kurangnya interaksi dengan anak. Selain itu orang tua kurang memahami materi pelajaran anak, dikarenakan pendidikan mengalamibanyak perkembangan. Sehingga kebanyakan orang tua acuh tak acuh terhadap apa yang dipelajari anak di sekolahnya dan hanya mementingkan kebutuhan berupa materi saja.

Berdasarkan hasil wawancara dengan Bapak Muhammad Yunus selaku wali kelas IV SD Negeri Banjarsari Kecamatan Ngadirejo, anak yang sering mendapatkan nilai ulangan jelek adalah anak yang tidak pernah mengerjakan tugas dan PR yang diberikan guru. Hal ini dapat disimpulkan bahwa anak yang tidak pernah mengerjakan tugas dan PR adalah anak yang kurang diperhatikan oleh orang tuanya ketika di rumah. Selain itu, beberapa anak yang sering mendapat nilai jelek adalah anak yang sering bermain sendiri dan mengobrol dengan temannya ketika proses belajar mengajar sedang berlangsung.

Dengan penelitian ini diharapkan dapat memberi motivasi kepada orang tua tentang pentingnya memperhatikan pendidikan anaknya agar anak mendapatkan hasil belajar yang memuaskan.

\section{Metode}

Penelitian ini menggunakan jenis penelitian deskriptif kualitatif.Penelitian kualitatif adalah penelitian yang bermaksud memahami fenomena tentang apa yang dialami oleh subjek penelitian misalnya perilaku, persepsi, motivasi, tindakan, dan lain-lain, secara holistik, dan dengan cara deskripsi dalam bentuk kata-kata dan bahasa, pada suatu konteks khusus yang alamiah dengan memanfaatkan berbagai metode ilmiah (Moleong, 2010:6).

Penelitian ini dilaksanakan di SD NegeriBanjarsari Kecamatan Ngadirejo Kabupaten Temanggung. Penelitian ini dilakukandi kelas IV pada semester gasal tahun ajaran 2019/2020.

Teknik yang digunakan adalah menggunakan wawancara secara langsung dengan guru dan siswa kelas IV SD Negeri Banjarsari, selanjutnya melakukan observasi dan membagikan quesioner (angket) kepada siswa. Data selanjutnya peneliti menggunakan dokumentasi untuk memperkuat data. penelitian.Teknik analisis data menurut Miles dan Huberman (Sugiyono, 2015 : 246) Aktivitas dalam analisis data, yaitu : data collection, data reduction, data display, dan conclusion drawing/verification.

\section{Hasil dan Pembahasan}

Penelitian ini dilaksanakan di SD Negeri Banjarsari yang mana merupakan Sekolah Dasar Negeri yang beralamat di KecamatanNgadirejo Kabupaten Temanggung. Penelitian ini dilaksanakan dengan bantuan partisipasi siswa kelas IV yang nantinya akan diambil beberapa siswa, guru kelas IV dan beberapa orangtua siswa kelas IV SD Negeri Banjarsari KecamatanNgadirejo Kabupaten Temanggung.

Tabel 01 Indikator bentuk perhatian orang tua

\begin{tabular}{|c|c|c|}
\hline Variabel & Sub Variabel & Indikator \\
\hline & $\begin{array}{l}\text { Pemberian } \\
\text { Bimbingan } \\
\text { dan } \\
\text { nasihat }\end{array}$ & $\begin{array}{l}\text { Orang tua memberi bantuan dan bimbingan } \\
\text { belajar kepada anak } \\
\text { Orang tua memberi nasihat untuk rajin belajar } \\
\text { Orang tua membantu mengatur jadwal belajar } \\
\text { anak } \\
\text { Orang tua mengingatkan mengerjakan tugas atau } \\
\text { PR anak }\end{array}$ \\
\hline & $\begin{array}{l}\text { Pengawasan } \\
\text { Terhadap } \\
\text { belajar }\end{array}$ & $\begin{array}{l}\text { Orang tua mengetahui hasil belajar anak } \\
\text { Orang tua mengetahui kegiatan anak di sekolah } \\
\text { Orang tua mengetahui mata pelajaran yang } \\
\text { kurang dikuasai anak }\end{array}$ \\
\hline Perhatian & Pemenuhan & $\begin{array}{l}\text { Orang tua mengetahui alat tulis yang dibutuhkan } \\
\text { anak } \\
\text { Orang tua mengetahui buku pelajaran yang }\end{array}$ \\
\hline
\end{tabular}




\begin{tabular}{|c|c|}
\hline $\begin{array}{l}\text { Kebutuhan } \\
\text { belajar }\end{array}$ & $\begin{array}{l}\text { dibutuhkan anak } \\
\text { Orang tua memberi perhatian dengan mengganti } \\
\text { alat tulis anak yang rusak }\end{array}$ \\
\hline $\begin{array}{l}\text { Penciptaan } \\
\text { Suasana } \\
\text { Belajar yang } \\
\text { nyaman }\end{array}$ & $\begin{array}{l}\text { Orang tua menyediakan tempat khusus belajar } \\
\text { anak } \\
\text { Orang tua mematikan TV ketika anak belajar }\end{array}$ \\
\hline $\begin{array}{l}\text { Pemberian } \\
\text { Penghargaan } \\
\text { Dan hukuman }\end{array}$ & $\begin{array}{l}\text { Orang tua memberi hadiah ketika anak mendapat } \\
\text { nilai bagus } \\
\text { Orang tua memarahi anak ketika anak malas } \\
\text { belajar } \\
\text { Orang tua memarahi anak ketika anak mendapat } \\
\text { nilai jelek }\end{array}$ \\
\hline
\end{tabular}

Indikator bentuk perhatian orangtua tersebut kemudian dikembangkan menjadi beberpa pernyataan angket untuk siswa yang berjumlah 15 butir pernyataan. Angket yang diberikan kepada siswa dapat diperoleh data mengenai tinggi rendahnya perhatian orangtua terhadap anak. Hasil angket dengan 37 siswa kelas IV SDN Banjarsari Kecamatan Ngadirejo Kabupaten Temanggung terkait perhatian orangtua dapat diperoleh presentase sebagai berikut.

Tabel 02 Kategori Presentase Hasil Angket Mengenai Perhatian Orangtua

Presentase Pehatian Orangtua

$80 \%-100 \%$
$70 \%-79 \%$
$60 \%-69 \%$
$<59 \%$$$
<59 \%
$$

Kategori Perhatian Orangtua

Sangat Cukup
Cukup

Kurang

Sangat Kurang

Perhatian orangtua dapat dikatakan sangat cukup apabila presentase perhatian orangtua $80 \%-100 \%$. Perhatian orangtua dapat dikatakan cukup apabila presentase perhatian orangtua $70 \%-79 \%$. Perhatian orangtua dapat dikatakan kurang jika presentase perhatian orangtua $60-$ $69 \%$. Perhatian orangtua dapat dikatakan sangat kurang jika presentase dibawah $59 \%$.

Tabel 03 Presentase Perhatian Orangtua

\begin{tabular}{lcc}
\hline \multicolumn{1}{c}{ Perhatian Orangtua } & $\begin{array}{c}\text { Jumlah Perolehan } \\
\text { (Siswa) }\end{array}$ & $\begin{array}{c}\text { Presentase } \\
(\%)\end{array}$ \\
\hline Sangat Cukup & 9 & $24,3 \%$ \\
Cukup & 12 & $32,4 \%$ \\
Kurang & 11 & $29,7 \%$ \\
Sangat Kurang & 5 & $13,6 \%$ \\
\hline
\end{tabular}

Perhatian sangat cukup di terapkan oleh 9 orangtua siswa kelas IV, sehingga presentase perhatian orangtua sangat cukup $24,3 \%$. Perhatian kurang di terapkan oleh 11 orangtua siswa kelas IV, sehingga presentase perhatian kurang $32,4 \%$, sedangkan perhatian kurang diterapkan oleh 11 orangtua siswa kelas IV sehingga presentase perhatian kurang $29,7 \%$. perhatian orangtua sangat cukup diterapkan oleh 12 orangtua siswa kelas IV dengan presentase terbanyak yaitu $32,4 \%$. Dengan demikian dapat dikatakan perhatian orangtua cukup dan kurang lebih dominan di terapkan oleh orangtua siswa kelas IV SDN Banjarsari Kecamatan Ngadirejo Kabupaten Temanggung kemudian di susul perhatian sangat cukup dan perhatian sangat kurang.

Peran perhatian orangtua dalam meningkatkan hasil belajar siswa adalah dengan cara memberikan bantuan dan bimbingan belajar kepada anak agar anak termotivasi dan merasa mendapat dorongan untuk lebih giat belajar. peran perhatian orangtua sangat berpengaruh 
besar terhadap hasil belajar siswa, karena waktu siswa lebih banyak di rumah. Orangtua memberikan perhatian dan bimbingan belajar yang bai kepada anak, maka hasil belajar anak juga baik.

Pemberian perhatian yang diberikan orangtua kepada anak, antara orangtua yang satu dengan yang lain tentu berbeda. Hal ini dilatar belakangi kesibukan orangtua serta pengalaman dalam memberikan cara untuk membimbing dan membantu anak dalam belajar yang berbeda. Jumlah siswa kelas IV SDN Banjarari Kecamatan Ngadirejo Kabupaten Temanggung adalah 37 siswa dengan latar belakang pekerjaan orangtua yang berbeda beda. Dari hasil penelitian, di dapatkan data mengenai perhatian orangtua yang berbeda beda serta korelasinya terhadap hasil belajar siswa.

Hasil analisis angket serta dokumen yang telah dilakukan peneliti menunjukan bahwa terdapat empat criteria perhatian orangtua yang diterapkan oleh orangtua siswa kelas IV SDN Banjarsari Kecamatan Ngadirejo Kabpaten Temanggung yaitu perhatian orangtua sangat kurang, perhatian orangtua kurang, perhatian orangtua cukup, perhatian orangtua sangat cukup. Hal tersebut didukung dengan hasil wawancara dengan guru kelas IV yaitu Bapak Muhammad Yunus, S.Pd yang mengatakan bahwa peran serta dari orangtua siswa masih $60 \%$ $70 \%$ dalam pendidikan anak terutama kontribusi terhadap kegiatan yang ada di sekolah.

Orangtua siswa memiliki latar belakang pekerjaan yang bermacam macam sehingga secara tidak langsung waktu dan tenaga orangtua sudah terkuras saat bekerja. Jam kerja yang begitu padat serta beban perekonomin keluarga yang ditanggung tidak sedikit akan berpengaruh terhadap kondisi social serta emosi orangtua dalam mempelakukan anak, namun di sisi lain masih terdapat orangtua yang peduli dengan anak terutama dalam hal pendidikan. Sehingga dapat dikatakan bahwa ada empat kategori perhatian yang diterapkan oleh orangtua siswa kelas IV SDN Banjarsari Kecamatan Ngadirejo Kabupaten Temanggung yaitu perhatian orangtua sangat cukup, perhatian orangtua cukup, perhatian orangtua kurang dan perhatian orangtua sangat kurang. Hasil analisis diperoleh sejumlah 12 orangtua menerapkan perhatian yang cukup kepada anak, menyusul perhatian orangtua kurang sejumlah 11 orang, kemudian perhatian orangtua sangat cukup di terapkan oleh 9 orangtua dan perhatian yang sangat kurang di terapkan oleh 5 orangtua siswa, selebihnya akan diuraikan dalam pembahasan berikut.

\section{Perhatian Orangtua}

Hasil penelitian yang sudah dilakukan terdapat empat kategori perhatian orangtua yang diterapkan orangtua siswa kelas IV SDN Banjarsari Kecamatan Ngadirejo Kabupaten Temanggung. Pertama perhatian sangat cukup dimiliki oleh $24,3 \%$ orangtua siswa, kedua perhatian cukup dimiliki oleh $32,4 \%$ orangtua siswa, ketigga perhatian kurang dimiliki $29,7 \%$ orangtua siswa dan keempat perhatian sangat kurang dimiliki oleh $13,6 \%$ orangtua siswa kelas IV SDN Banjarsari Kecamatan Ngadirejo Kabupaten Temanggung. Data tersebut diperoleh dari hasil analisis angket serta dokumen yang menunjukan bahwa tingkat perhatian terbanyak yang diterapkan orangtua siswa kepada anak yaitu perhatian cukup.

Penerapan perhatian orangtua memiliki korelasi dengan pemerolehan hasil belajar siswa yang diterapkan di sekolah. Berdasarkan penelitian yang dilakukan peneliti pada obyek penelitian yaitu 4 siswa yang telah dikategorikan berdasarkan hasil belajar, didapatkan data bahwa sebagian besar anak yang mendapat hasil belajar tinggi disebabkan oleh perhatian orangtua yang sangat cukup, kemudian anak yang mendapat hasil belajar rendah disebabkan perhatian orangtua yang kurang. Orangtua dengan keberagaman latar belakang pekerjaan yang berbeda beda tentu akan mempengaruhi banyak sedikitnya perhatian orangtua yang dilakukan kepada anak. Sehingga waktu dan tenaga sudah terkuras dengan pekerjaan.

Berdasarkan latar belakang pekerjaan orangtua siswa yang berbeda beda antara orangtua satu dengan yang lain menjadi faktor kecenderungan orangtua dalam menerapkan perhatian kepada anak. Meskipun begitu pasti semua orangtua ingin memberikan perhatian yang terbaik kepada anak sehingga anak akan mendapatkan hasil belajar yang maksimal. Orangtua sebagai pengasuh anak memainkan peranan yang sangat menentukan dalam perkembangan anak. Bila orangtua berhasil mendidik dan membimbing anak dirumah, tentu saja pendidikan disekolah akan berhasil dengan baik. Namun sebaliknya apabila orangtua gagal mendidik anaknya dirumah, tentu saja akan lahir generasi yang rusak, seperti anak yang berperilaku agresif, bahkan perilaku perilaku yang bermasalah lainnya. (Syamaun, 2012: 27).

Dalyono (2010: 59) mengatakan bahwa tinggi rendahnya pendidikan orangtua, besar kecilnya penghasilan orangtua, serta rukun tidaknya orangtua dengan anak anaknya, tenang 
atau tidaknya situasi dalam rumah, semua itu turut mempengaruhi hasil belajar anak. Dalam kegiatan belajar dirumah, orangtua merupakan contoh terdekat dari anak anaknya. Hal ini sejalan dengan pandangan Ahmadi dan Supriyono (2013: 87) yang menyatakan bahwa belajar memerlukan bimbingan dari orangtua agar sikap dewasa dan tanggung jawab belajar, tumbuh dalam diri anak. Orangtua yang sibuk bekerja, terlalu banyak anak yang diawasi, sibuk organisasi, berarti anak tidak mendapatkan pengawasan bimbingan dari orangtua, sehingga kmeungkinan akan mengalami kesulitan belajar.

\section{Prestasi Belajar Siswa}

Berdasarkan penelitian yang telah dilakukan, hasil belajar siswa pada rata rata ulangan harian selama satu semester ganjil beragam, ada siswa yang mendapatkan kategori hasil belajar yang tinggi dan rendah. Peneliti mengambil obyek penelitian sejumlah 4 siswa dengan pembagian hasil belajar yang telah dikaegorikan yaitu 2 siswa yang memperoleh hasil belajar tertinggi dan 2 siswa yang memperoleh hasil belajar paling rendah. Siswa dengan rata rata ulangan harian tertinggi nomor 1 mendapatkan nilai 94,5 yang dapat dikategorikan hasil belajar yang sangat baik. Siswa dengan rata rata ulangan harian tertinggi nomor 2 mendapatkan nilai 93 yang dapat dikategorikan hasil belajar yang sangat baik. Kemudian siswa yang mendapatkan rata rata ulangan harian ter rendah nomor 1 mendapatkan nilai 60,3 yang dapat dikategorikan hasil belajar yang cukup. Siswa yang mendapatkan rata rata ulangan harian ter rendah nomor 2 mendapatkan nilai 60,4 yang dapat dikategorikan hasil belajar yang cukup. Setelah dianalisis dapat disimpulkan hasil belajar siswa kelas IV SDN Banjarsari Kecamatan Ngadirejo Kabupaten Temanggung termasuk dalam kategori sangat baik, baik dan cukup karena tidak ada siswa yang mendapatkan rata rata dibawah 50 yang berarti kurang ataupun gagal.

Hasil belajar yang dicapai siswa diantaranya dipengaruhi oleh beberapa faktor yaitu faktor internal dan faktor eksternal. Faktor internal merupakan faktor dari dalam diri sendiri yang didalamnya termasuk minat sertafaktor eksternal yang meliputi lingkungan keluarga dan lingkungan sekolah. Dalam kegiatan pembelajaran di sekolah, kedekatan positif yang terjalin antara guru dengan murid, harus menimbulkan suasana pembelajaran yang menyenangkan. Susana belajar yang menyenangkan dapat mempengaruhi kualitas belajar dalam bidang studi tertentu sehingga hal ini berdampak pada hasil belajar siswa. semakin baik kualitas belajar yang didapatkan maka semakin baik prestasi belajar yang diperoleh, begitupun sebaliknya. Hal ini sejalan dengan pendapat Hamdani (2011: 137-146) yang mempengaruhi hasil belajar dibagi menjadi dua bagian, yaitu faktor dari dalam (intern) dan faktor dari luar ( ekstern). Faktor intern adalah faktor yang berasal dari siswa yang dapat mempengaruhi belajarnya. Pengnalan terhadap faktor faktor yang mempengaruhi hasil belajar penting sekali artinya dalam rangka mmbantu murid dalam mencapai hasil belajar yang sebaik baiknya.

Temuan hasil penelitian yang dilakukan di SDN Banjarsari Kecamatan Ngadirejo Kabupaten Temanggung dapat diketahui bahwa sebagian besar perhatian orangtua yang diterapkan kepada anak sangat berpengaruh terhadap hasil belajar anak. Perhatian orangtua yang sangat cukup akan membuat anak termotivasi dan lebih giat untuk belajar sehingga anak akan mendapatkan nilai yang maksimal sedangkan perhatian orangtua yang kurang akan membuat anak menjadi malas untuk belajar, anak akan lebih memilih menghabiskan waktunya untuk bermain dibandingkan belajar. Dengan demikian terdapat korelasi antara perhatian yang diberikan orangtua dengan hasil belajar iswa kelas IV SDN Banjarsari Kecamatan Ngadirejo Kabupaten Temanggung.

Namun ternyata peneliti menemukan terdapat hasil temuan yang baru yang mempengaruhi hasil belajar siswa. peneliti menemukan fakta baru bahwa ada faktor eksternal selain lingkungan keluarga yaitu perhatian orangtua ternyata lingkungan sekolah juga dapat mempengaruhi hasil belajar siswa. Peneliti menemkan adanya keterkaitan guru dan suasana belajar di kelas yang juga mempengaruhi hasil belajar siswa. The learning process that is held interactively, fun challenging, inspiring, motivating students to actively participate makes reasoning very important for students to increase creativity, independence, develop problem solving and thinking skills critically. Suliyanto, Sunardi, Anitah, Gunahardi (Jurnal Advances in Social Science, Education and Humanities Research, Vol. 422) diperkuat dengan hasil wawancara dengan guru kelas IV, menrut hasil wawancara, guru juga memiliki peran penting dalam hal hasil belajar siswa. Cara mengajar guru yang variasai atau tidak monoton akan membuat sisa tidak bosan ketika mengikuti pembelajaran di kelas. Ketika guru mengajar dan sisa tidak merasa bosan maka siswa akan mudah menyerap pembelajaran yang disampaikan oleh guru. 


\section{Simpulan dan Saran}

Berdasarkan temuan hasil analisis penelitian dan pembahasan yang dapat disimpulkan bahwa: 1) Dari data hasil penelitian, peneliti menemukan kategori tingkat perhatian orangtua yang diterapkan kepada siswa kelas IV SDN Banjarsari Kecamatan Ngadirejo Kabupaten Temanggung adalah perhatian cukup dengan presentase tertinggi yaitu $32,4 \%$ kemudian disusul kategori tingkat perhatian orangtua kurang dengan presentase $29,7 \%$ di susul kategori tingkat perhatian orangtua sangat cukup dengan presentase $24,3 \%$ dan perhatian orangtua sangat kurang mendapat presentase 13,6\%. 2) Hasil belajar siswa kelas IV SDN Banjarsari Kecamatan Ngadirejo Kabupaten Temanggung dapat dikatakan sangat baik karena lebih dari $50 \%$ siswa mendapatkan rata rata nilai di atas 80 . Di susul dengan $29,7 \%$ siswa mendapat rata rata hasil belajar baik dan $16,2 \%$ siswa mendapatkan hasil belajar yang cukup yang berarti semua siswa mendapatkan rata rata nilai diatas 50 . 3) Perhatian orangtua berpengaruh terhadap hasil belajar siswa. Siswa dengan perhatian yang sangat cukup mempunyai rata rata hasil belajar yang sangat baik. Siswa dengan perhatian yang kurang mempunyai rata rata hasil belajar yang cukup. Namun tidak sepenuhnya perhatian orangtua mempengaruhi hasil belajar siswa melainkan karena ada faktor lain seperti guru dan suasana belajar di kelas serta faktor belajar lainnya.

Berdasarkan simpulan dan temuan dari penelitian yang telah dilakukan mengenai korelasi antara perhatian orangtua dengan hasil belajar kognitif siswa maka peneliti memberikan saran sebagai berikut. 1) Bagi guru sangat diharapkan menjalin komunikaasi yang baik dengan orangta siswa agar kemajuan belajar dan kendala yang dialami siswa dalam belaar dapat diatasi dengan baik. Guru merupakan pendidik setelah orangtua di rumah, hendaknya memperhatikan perkembangan siswa terutama yang mempunyai hasil belajar rendah dan mempunyai kesulitan belajar. 2) Bagi orangtua diharapkan memberikan perhatian lebih kepada anak, serta memberikan bantuan dan bimbingan dalam belajar anak. Orangtua harus lebih member dukungan penuh terhadap kegiatan positif anak agar anak dapat mengembangkan prestasi yang dimiliki dalam diri. Orangtua diharapkan untuk tidak terlalu member perhatian yang cenderung memanjakan anak karena hal tersebut dapat membuat anak menjadi memanfaatkan untuk hal yang tidak baik. 3) Bagi siswa diharapkan memiliki semangat belajar yang tinggi. Sehingga dapat mencapai hasil belajar yang maksimal di sekolah.

\section{Daftar Pustaka}

Abin Syamsudin, Makmun. 2009. Psikologi Kepribadian. Bandung: PT. Remaja Rosdakarya.

Abu, Ahmadi. 2004. Psikologi Umum. Jakarta: RiekaCipta.

Ahmadi, Abu\&Widodo Supriyono. 2004. Psikologi Belajar. Jakarta: RinekaCipta.

Ahmadi, Ruslam. 2014. Metode penelitian Kualitatif. Cetakan ke-1. Yogyakarta: Ar-ruzz Media.

Arikunto, S. 2010. Prosedur Penelitian Suatu Pendekatan Praktik. Jakarta: RinekaCipta.

Aswan, Zain. Bahri, Syamsul. Djamarah. 2006. Strategi Belajar Mengajar. Jakarta: PT. RinekaCipta.

A'la, Rofiqul. 2016. Perhatian Orang Tua dan Motivasi Belajar Siswa. Jurnal Madaniyah, Vol. 2, Edisi 11.

A.M. Sardiman. 2007. Interaksi dan Motivasi Belajar Mengajar. Jakarta: PT. GrafindoPersada.

A.K, Mudjito. 2007. Pedoman Bidang Pengembangan Pembiasaan di Taman Kanak Kanak. Jakarta : Departemen Pendidikan Nasional.

Bimo, Walgito. 2004. Pengantar Psikologi Umum. Yogyakarta: Andi. 
Bujuri, D.A. 2018. Analisis Perkembangan Kognitif Anak Usia Dasar dan Implikasinya dalam Kegiatan Belajar Mengajar. Jurnal Literasi. Vol. 9, No.1.

Depdiknas.2008. Kamus Besar Bahasa Indonesia. Indonesia: Gramedia Pustaka

Fathurrohman,Taufik. Muhammad. Pengaruh Perhatian Orang Tua Terhadap Prestasi Belajar Siswa. Journal Student UNY (diunduh 22 Juni 2019).

Hijriati. 2016. Tahapan Perkembangan Kognitif Pada Masa Early Childhood. Journal Ar-Raniry UIN Sunan Kalijaga Yogyakarta. Vol. 1 No. 2.

Mahmud. 2011. Metode Penelitian Pendidikan. Bandung: Pustaka Setia.

Moelong, Lexy J. 2010. Metodologi Penelitian Kualitatif. Bandung: Remaja Rosdakarya.

MS Sumantri. (2005). Pengembangan Ketrampilan Motorik Anak Usia Dini. Jakarta : Dinas Pendidikan

Nisa, Afiatin. 2015. Pengaruh Perhatian Orang Tua dan Minat Belajar Siswa Terhadap Prestasi Belajar IImu Pengetahuan Sosial. Jurnal IImiah Kependidikan. Vol. 11 No. 1.

Rosmalinda, Desy. Zulyanty, Marni. 2019. Dukungan Orang Tua Terhadap Motivasi Belajar Siswa Kelas Unggul. Jurnal Gentala Pendidikan Dasar, Vol. 4 No. 1.

Saeful Rahmat, Pupu. Penelitian Kualitatif. Jurnal EQUILIBRIUM, Vol. 5 No. 9 (diunduh 22 Juni 2019).

Slameto. 2010. BelajardanFaktorFaktor yang Mempengaruhinya. Jakarta: Rineka Cipta.

Soegeng, A.Y. Nisa, Zuhrotun. 2014. Hubungan Antara Perhatian Orang Tua dan Hasil Belajar Pada Pembelajaran Tematik Integratif Siswa Kelas IV SD Negeri Kembangarum 2 Mranggen Demak. Journal UPGRIS. Vol. 4, No. 2.

Sugiyono. 2009. Metode Penelitian Kualitatif dan R\&D. Bandung: Alfabeta

Sulianto, Joko. Sunardi. Sri Anitah. Gunardi. 2019. Development Of an Advanced Organizer Model Based on Open-Ended to Increase Student Punishment in Elementary Schools. (Jurnal Advances in Social Science, Education and Humanities Research, Vol. 422)

2020. An Analysis of Primary School Teachers Characters Learning Process on Teaching Model Development Named Open Ended Approach-based Advance Organizer on Students Reasoning Skill. (Universal Journal of Educational Research 8(3D): 60-66)

Sunain. 2017. Pengaruh Tingkat Pendidikan Orang Tua Terhadap Tingkat Kecerdasan dan Keaktifan Siswa dari Kelas Satu Sampai dengan Kelas Enam Pada Semester I. Jurnal Pendidikan Vol. 6 No. 2.

Suryabrata, Sumadi. 2004. Psikologi Pendidikan. Jakarta: PT Raja grafindo Persada.

Syafi'l, Ahmad. Marfiyanto, Tri. Siti Kholidatur Rodiyah. 2018. Studi Tentang Prestasi Belajar Siswa Dalam Berbagai Aspek Dan Faktor Yang Mempengaruhi. Jurnal Komunikasi Pendidikan, Vol. 2 No. 2. 